\title{
THE RELATIONS BETWEEN MUSICIANSHIP AND CORE COMPETENCIES IN PROFESSIONAL MUSIC TRAINING-THE TUT EXPERIENCE
}

\author{
Hua Hui Tseng \\ Tainan University of Technology (Taiwan)
}

\begin{abstract}
After being asked to respond to the Arts Education Act of 2015 by the Ministry of Education, Taiwan, concerning curricula and their impact on music education, what follows are some observations and reflections from the Tainan University of Technology (TUT), Taiwan, about its educators' experiences of teaching undergraduate music and music degrees. The idea put forward is that skills/knowledge competency reflects an emergent sensibility in contemporary music cultures, and this represents an opportunity for music educators to reconfigure and strengthen their pedagogical approaches. By recognizing the legitimacy of new and varied forms of musicianship and acknowledging the ways in which course curricula continue to grow in their range of practices and necessary literacies, strategies can be developed to support broader, cohesive, inclusive, diverse, meaningful, and useful experiences for music students.
\end{abstract}

Keywords: Curriculum, musician, core competencies.

\section{Introduction}

Contemporary society demands that people add value, and for musicians, it is no different. The demand implies offering holistic musical learning experiences that accommodate technology and allow musicians to add value to their communities. Kardos (2018) noted that artists and practitioners who generate influence and esteem in contemporary music might not look or sound like music students do, and the natural latency between curriculum development and the speed of life means higher music education programs that seek to reflect trends in contemporary cultures will inevitably lag behind. According to Abankwa and Mikkilä-Erdmann (2018), the lack of alternative programs for teacher training and the limited flexibility to obtain professional pedagogical qualifications as a musician is surprising because instrumental/vocal teachers need to have a broader understanding of their working responsibilities and possibilities and an understanding that goes beyond teaching artistry and embraces working on more general levels of music and art education (Abankwa \& Mikkilä-Erdmann, 2018). Berr (2016) noted that artistry first requires mastery of the basics because a skilled, knowledgeable, artistic and experienced musician acts as a source of inspiration for students in developing their own musicianship (Abankwa \& Mikkilä-Erdmann, 2018).

The concept of musicianship is usually thought of as part of a curriculum, and musicianship can permeate the classroom by handling most activities artistically (Berr, 2016). As stated in England's Action Ideal VIII by the Mayday Group (2018), ideally, music education makes important contributions to musical cultures (Kardos, 2018). This connection should be seen the manifest link between music research and the learning taking place in educational institutions. Kardos (2018) noted beyond issues of vocational viability of graduates, specializations can foster potentially crippling literacy issues, for example, music performance graduates who cannot operate technology or music technologists who cannot read music, etc. Conventional music curriculum creates boundaries between practices, which in the real world are becoming increasingly blurred and/or irrelevant. It is critical that professional music training provide a wide range of practical experiences in combination with professional musicianship and the cultivation of artistic personalities to indicate broader understanding of exciting music cultures and the possibility for inquiry-based learning.

The skills/knowledge competencies were recently adopted by Cole (2014) and Rohwer and Henry (2004), and the music teaching found herein continues to be relevant because of (a) the importance of skills/knowledge competencies; (b) the difficulty of acquiring skills/knowledge competencies; (c) the differences between the importance of teaching competency and acquisition ratings; (d) the benefits of university coursework; and (e) the potential improvements to coursework that are encompassed in three categories of skills/knowledge components, (teaching, personal, and musical skills and behaviors), each with individual competency items. 
Professional music training programs are challenged by major changes in the sociocultural and educational landscape. In response to Taiwan's societal challenges, such as current issues about music education policy, the Ministry of Education in Taiwan (1997) amended the Arts Education Act (AEA) that outlined the curriculum for study in the performing arts in 1997. The AEA of 1997 was related directly to Taiwan's art education reform (Lau \& Li, 2013). This new milestone provided a solid foundation in music education in Taiwan for all students (Ministry of Education, Taiwan, 1997). The TUT, Taiwan, Music Department's seven-year program from high school directly to a bachelor's degree in vocational education serves as an example for incorporating educational interventions based on Teachout's (1997) three categories of skills/knowledge components, namely, teaching, personal, and musical skills and behaviors as core competencies.

Recent curricular redesign at the TUT music department presented the opportunity to place greater emphasis on the three core competencies in the first two years of the music curriculum and transition basic Fundamentals (Ear and Mind) of Music courses into outcomes-based models. Introductory Ear-Training is one of several basic Fundamentals (Ear and Mind) of Music courses from the "old" curriculum that was completely revised. The Taiwan's Ministry of Education 2014 Curriculum Guidelines for the 12-Year Basic Education (covering elementary, junior high, and upper secondary school stages) core competencies drove the process of integrating first-year Theory, Harmony, Counterpoint, Sight Singing, Ear Training, Dictation, Form and Analysis Orchestration, Instrumentation, Keyboard Harmony, and Composition and related Theoretical/Aural skills into one course (Ministry of Education, Taiwan, 2014). As a result, an 18-week (720-contact-hour) hybrid didactic block given the title "Music Theory" was implemented. The course is comprised of more than 40 educational interventions that each target one or more core competencies.

\section{Relationships between musicianship and core competencies}

The aim of this research is to explore the assumed relationship between musicianship and core competencies (see Figure 1). It was assumed that musicianship, as naturally associated with knowing how to listen and think about music at the strategic level, is the category starting the relationship. The case of the TUT was examined. The main reasons for the choice are that the study has been ongoing over a number of years, it offers a seven-year program from high school directly to a bachelor's degree in vocational education, and artistry first requires mastery of the basics, suggesting that TUT is a leader in professional music training.

Figure 1. Relationships between musicianship, core competencies, and curriculum.

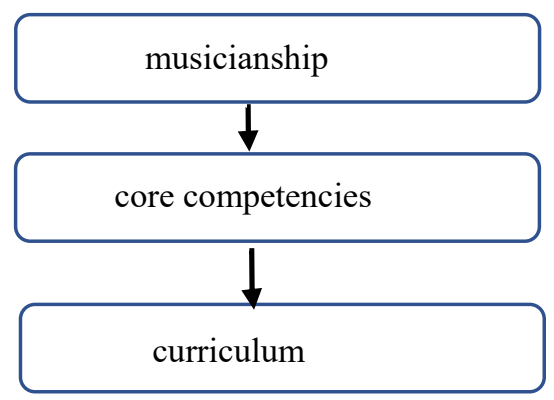

The curriculum falls into three main categories in the TUT's music department: Musicianship, Applied Studies and Ensembles, and Major Requirements. The primary focus of an integrated or holistic curriculum is not on the disciplines themselves but on the themes, the issues, or the phenomena (American Association for the Advancement of Science, 2000). A thematic approach is used to integrate curricular content by common topical areas or themes into interdisciplinary and multidisciplinary units of study (Merritt, 2019). In the 1930s, American educator and composer Randall Thompson, supported by the Carnegie Foundation, conducted a study to determine the extent to which musical education was an essential component of education as a whole (Nelson, 2005). Nelson (2005) concluded by discussing the significance of a critical, holistic approach for processes of acquired expertise to policy. The study was influential across the country in encouraging the integration of musical studies with other disciplines.

As an example, with respect to Integration in a chamber music class, the teacher might take time in class to dissect "Archduke Trio" as students rehearse the piece. For example, the teacher can alert students to what was going on in music history at the time that Beethoven composed this piece and discuss how it is similar or different to anything that audiences had heard before. Much like a college music theory lecture, the teacher can discuss with the students and raise awareness about how Beethoven uses triadic tonality and sonata-form in inventive ways. The teacher might also focus on stage presence and reflect on what worked 
and what did not work. The purpose of learning this piece goes beyond just playing good music well. It might incorporate an intentional introduction to new musical discourses and tools for students to add to their cognitive understanding of how music works (Table 1).

Table 1. Integrated curriculum, instruction/teaching, learning, related strategies, and the associated terminology.

\begin{tabular}{|l|l|}
\hline Curriculum & Instruction/Teaching \\
\hline $\begin{array}{l}\text { Chamber Music, for example, using Beethoven's - } \\
\text { Piano Trio Op. 97 "Archduke Trio." }\end{array}$ & $\begin{array}{l}\text { The Chamber Music requirements that are } \\
\text { integrated into the performance degree programs. }\end{array}$ \\
\hline Integrated & Integrated Curriculum \\
\hline $\begin{array}{l}\text { Incorporate Chamber Music into students' degree } \\
\text { curricula ("ensemble participation"). }\end{array}$ & $\begin{array}{l}\text { These include Sonata Classes, String \& Piano } \\
\text { Chamber Music, and The Intensive Quartet } \\
\text { Seminar. }\end{array}$ \\
\hline Integration & Learning \\
\hline $\begin{array}{l}\text { Regarding musicianship, instructors need to help } \\
\text { their students develop a confident, respectful, and } \\
\text { expressive stage presence. }\end{array}$ & $\begin{array}{l}\text { A certain level of body awareness is key as this } \\
\text { will assist in the students' expressive ability and } \\
\text { to use their physiology to support their musicality } \\
\text { and technical prowess. }\end{array}$ \\
\hline $\begin{array}{l}\text { Strategies } \\
\text { The didactic skills that can be cultivated } \\
\text { specifically through the study of Chamber Music } \\
\text { include (a) the ability to constructively self-assess } \\
\text { both as an individual and as a group, and (b) the } \\
\text { development of coaching, rehearsal, and basic } \\
\text { time management strategies and skills. }\end{array}$ & $\begin{array}{l}\text { The holistic instruction of performance and } \\
\text { pedagogy appeared as (a) modeling, (b) guided } \\
\text { thinking, (c) overt instruction of pedagogy, and } \\
\text { (d) experience. }\end{array}$ \\
\hline
\end{tabular}

\section{Application of skills/knowledge competencies in the music theory block}

The 2020 National Association of Schools of Music (NASM) Handbook provides access to the NASM standards and guidelines that include proposed revisions to NASM standards currently open for comment, including the Association's helpful Basic Competency Index by Discipline and Specialization for Undergraduate Degrees in Music (NASM, 2020). The NASM Handbook indicates standards applicable to all professional undergraduate music degrees. Expert status is established by these criteria: (a) common body of knowledge and skills, including performance, musicianship skills and analysis, composition/improvisation, history and repertory, and synthesis, (b) general studies competencies, and (c) recommendations for professional studies.

Each of the NASM core competencies is addressed below with descriptions of some of the specific educational interventions currently employed in the music theory block at the TUT Music department. This study's intent is not to evaluate the effectiveness of individual interventions but to create awareness about the variety of options for incorporating core competencies into the basic Fundamentals (Ear and Mind) of Music portion of undergraduate music curricula. For example, the ears perceive only what the knowing mind can understand. Thus, critical listening skills come from both knowing what is heard and for what to listen (Wang, 2017). For example, a teacher might encourage her students to listen to great performances that provide aural models that foster the cursory mind-ear connection (cognitive). Next, she could invite students to engage the ear to critically discriminate what is heard in performances and practice rooms in search of differing subtleties to help students gain clarity and form aesthetic concepts and opinions (emotional). Furthermore, the teacher may urge students to listen to the orchestral, chamber, vocal and solo instrumental works of the composers they study (spiritual). Table 2 at the end of the article lists the educational interventions possible. 
Table 2. Educational interventions in the music theory block targeting MOE core competencies.

\begin{tabular}{|c|c|}
\hline Personal & Musical knowledge \\
\hline $\begin{array}{l}\text { Students might be given comparative listening } \\
\text { projects; after being given the score, students } \\
\text { would evaluate two different performances of the } \\
\text { same short work or section of a piece. }\end{array}$ & $\begin{array}{l}\text { Three categories of skills/knowledge components } \\
\text { comprised of teaching, personal, and musical } \\
\text { skills and behaviors are included each with } \\
\text { individual competency items. }\end{array}$ \\
\hline $\begin{array}{l}\text { Faculty deal with Sight Singing in a number of } \\
\text { ways, including allowing students to choose a } \\
\text { method that seems comfortable for them (either } \\
\text { fixed Do, moveable Do, numbers, note names, } \\
\text { etc.) or using syllables for some exercises but not } \\
\text { for others. }\end{array}$ & $\begin{array}{l}\text { All undergraduate music majors must satisfy both } \\
\text { the written music theory and aural skills } \\
\text { requirements, which are team taught by } \\
\text { theory/composition teachers. }\end{array}$ \\
\hline $\begin{array}{l}\text { Emphasizing musical expression more and giving } \\
\text { students additional "hands-on" experiences; Ear } \\
\text { Training and Sight Singing classes (and music } \\
\text { theory) may more effectively awaken and develop } \\
\text { students' musicality and musicianship. }\end{array}$ & $\begin{array}{l}\text { Philosophical approaches are introduced by using } \\
\text { different musical tools to teach musical skills } \\
\text { (e.g., fixed or movable Do, La, or Do-based } \\
\text { minor) as corresponding to the purpose and need } \\
\text { for music theory instruction. }\end{array}$ \\
\hline Teaching & $\begin{array}{l}\text { An electronic audience response system is used } \\
\text { for daily formative feedback addressing } \\
\text { individual and group questions. }\end{array}$ \\
\hline $\begin{array}{l}\text { Music theory block runs concurrently with the } \\
\text { placement examination curriculum. }\end{array}$ & $\begin{array}{l}\text { A skills assessment (dictation, sight-singing, and } \\
\text { keyboard reading) and written theory assessment } \\
\text { (analysis, figured bass realization, etc.) are } \\
\text { evaluated by taking placement examinations in } \\
\text { both music theory and aural skills. }\end{array}$ \\
\hline $\begin{array}{l}\text { All undergraduate music majors must satisfy both } \\
\text { the written music theory and aural skills } \\
\text { requirements. }\end{array}$ & $\begin{array}{l}\text { Written theory may be better addressed primarily } \\
\text { by ear (e.g., meter, when to raise scale degree } 7 \text { in } \\
\text { minor keys, harmonic rhythm, resolving tendency } \\
\text { tones). } \\
\text { Aural skills include: } \\
\text { - hearing and adjusting intonation while playing } \\
\text { - hearing the quality of a chord } \\
\text { - hearing and recognizing pitches in a melody } \\
\text { - } \quad \text { tapping a rhythm that you have heard } \\
\text { - } \quad \text { singing a melody at sight from written music } \\
\text { without the aid of a piano or other instrument. }\end{array}$ \\
\hline $\begin{array}{l}\text { Introduction to music has students work } \\
\text { backwards using different kinds of musical } \\
\text { notation, melodic systems, harmonies, meters, and } \\
\text { rhythmic techniques with the goal of attaining basic } \\
\text { competence in the performance and creating music } \\
\text { to explore scale, mode, rhythm, meter, texture, } \\
\text { and form, with reference to a diverse range of } \\
\text { music. }\end{array}$ & $\begin{array}{l}\text { - Musical skills include chord analysis and } \\
\text { modulation. } \\
\text { - Chord analysis includes how a chord is related } \\
\text { to the key and to the other chords in a piece of } \\
\text { music. } \\
\text { - Modulation occurs when a longer succession } \\
\text { of chords emphasizes a new tonic, leading to } \\
\text { the perception of a new key. }\end{array}$ \\
\hline $\begin{array}{l}\text { Students develop their listening skills in the areas } \\
\text { that make music. }\end{array}$ & $\begin{array}{l}\text { How well can student scrutinize and analyze a } \\
\text { song? }\end{array}$ \\
\hline
\end{tabular}

\section{Conclusion}

Among the basic competencies by discipline and specialization in the TUT Music Department curriculum, Music Theory was the logical starting point for implementing competency-based education because the "often" or "always" included musical competencies (Robinson, 2019) already included essential standards; in addition, activities with those musical competencies and theory-based strategies were in place. It is possible that music theory is unique among the core music curriculum traditionally included in university coursework with its many opportunities to help students toward all three NASM core competencies. Future work is needed to integrate all essential competencies, experiences, and opportunities across disciplines to further connect them to professional practices and make them outcomes-based so that every learner develops the skills, expertise, and knowledge to survive and thrive in the twenty-first century. 


\section{References}

Abankwa, J., \& Mikkilä-Erdmann, M. (2018). Piano teacher education in Finland and Germany: Targeted competencies and respective learning environments of two cases. International Journal of Music Education, 36(4), 616-629 (C) The Author(s) 2018 Article reuse guidelines: sagepub.com/journalspermissions DOI: 10.1177/0255761418775130 journals.sagepub.com/home/ijm

American Association for the Advancement of Science. (2000). Designs for science literacy. New York, NY: Oxford University Press.

Berr, B. (2016). Musicianship rules. American Music Teacher. 65(6), 64-64.

Cole, M. R. (2014). An examination of cooperating teachers' observations of their student teachers in the areas of personal, teaching, and musical skills in the elementary classroom (Doctoral dissertation). Available from ProQuest Dissertations and Theses database. (UMI No. 3617588)

Hendrixson, C. (2015). Holistic education in a secondary band classroom. Retrieved from https://repository.tcu.edu/bitstream/handle/116099117/10343/Caleb_Hendrixson_Honors_Thesis.p df? sequence $=1 \&$ isAllowed $=y$

Kardos, L. (2018). Making room for 21st century musicianship in higher education. Action, Criticism, and Theory for Music Education, 17(1), 33-47. doi:10.22176/act17.1.33

Lewis, L. K. (2014). A model for developing a holistic collegiate curriculum for string performance and pedagogy (Doctoral dissertation). Available from ProQuest Dissertation and theses database. (UMI No. 3638399)

Merritt, R. D. (2019). Integrated curriculum. Research Starters Education, (4/1), 1.

Miksza, P., Roeder, M., \& Biggs, D. (2010). Surveying Colorado band directors' opinions of skills and characteristics important to successful music teaching. Journal of Research in Music Education, 57, 364-381. doi:10.1177/0022429409351655

Ministry of Education, Taiwan (2014). Curriculum guidelines of 12- year basic education. Retrieved from https://www.naer.edu.tw/ezfiles/0/1000/img/52/129488083.pdf

$\begin{array}{lllll}\text { Ministry of } & \text { Education, } & \text { Taiwan. } & \text { (1997). } & \text { Retrieved }\end{array}$ https://law.moj.gov.tw/ENG/LawClass/LawHistory.aspx?pcode=H0170037

National Association of Schools of Music (2020). National association of schools of music handbook 201920. Retrieved from https://nasm.arts-accredit.org/wp-content/uploads/sites/2/2020/01/M-2019-20Handbook-02-13-2020.pdf

Nelson, A. J. (2005). Cacophony or harmony? Multivocal logics and technology licensing by the Stanford University Department of Music. Industrial and Corporate Change, 14 (1), 93-118 doi:10.1093/icc/dth045

Nierman, G. E. (2017). Report from NAfME: The ISME national affiliate in the United States of America. Retrieved August 16, 2020, from https://www.isme.org/news/report-nafme-us

Robinson, E. (2019). An examination of North Carolina music educators' preferences of musical competencies (Master's thesis). Available from ProQuest Dissertation and Theses database. (UMI No. 27629154)

Rohwer, D., \& Henry, W. (2004). University teachers' perceptions of requisite skills and characteristics of effective music teachers. Journal of Music Teacher Education, 13(2), 18-27. doi:10.1177/10570837040130020104

Teachout, D. J. (1997). Preservice and experienced teachers' opinions of skills and behaviors important to successful music teaching. Journal of Research in Music Education, 45, 41-50. doi:10.2307/3345464

Wang, E. (2017). This and that. American Music Teacher, 66(6), 52-53. 